\title{
Tests for evaluating the physiological quality of pitaya seeds
}

\section{Testes para a avaliação da qualidade fisiológica de sementes de pitaia}

\author{
Thiago Alberto Ortiz ${ }^{1 *}$; Aline Moritz ${ }^{1}$; Lúcia Sadayo Assari Takahashi²; \\ Mariana Ragassi Urbano 3
}

\begin{abstract}
Germination test is used to assess the physiological quality of seeds; however, since it is carried out under ideal conditions, this test has not been shown sufficient for this purpose. Instead, it is possible to use vigor tests, although the lack of standardized methodologies has reduced their applicability and reproducibility. Thus, this study aimed to develop methodologies for conducting tests of germination, accelerated aging, and electrical conductivity for the evaluation of the physiological quality of pitaya seeds. For this purpose, seeds from ripe Hylocereus undatus fruits were used. A completely randomized experimental design was used with four replications. The physiological quality of the seeds was assessed using germination, accelerated aging, and electrical conductivity tests, and the speed of germination index (SGI) and mean germination time (MGT) were determined for both the germination test and accelerated aging test. For the statistical analysis, we performed regression model adjustments and calculated the Pearson correlation coefficient $(\mathrm{p}<0.05)$. The germination test for $H$. undatus seeds can be performed at $25^{\circ} \mathrm{C}$, with the aim of reaching the highest SGI and lowest MGT values. The accelerated aging test can be conducted at $43{ }^{\circ} \mathrm{C}$ for $48 \mathrm{~h}$, because combining these factors favors the expression of seed vigor, allowing seeds to achieve the maximum SGI and minimum MGT, while reducing the time of the assay. The electrical conductivity test can be performed using 25 seeds at a temperature of $30^{\circ} \mathrm{C}$ and a water volume of $10 \mathrm{~mL}$, since under these conditions there is less interference from external factors on the leachate content of the solution.
\end{abstract}

Key words: Accelerated aging, cactaceae, electrical conductivity, germination, Hylocereus undatus, vigor

\section{Resumo}

O teste de germinação é utilizado na avaliação da qualidade fisiológica de sementes; porém, devido à sua condução em condições ideais, não tem se mostrado suficiente para este propósito. Nesse sentido, há a possibilidade de recorrer aos testes de vigor, conquanto, a ausência de metodologias padronizadas tem dificultado a sua aplicabilidade e reprodutibilidade. Assim, o trabalho teve como objetivo determinar as metodologias dos testes de germinação, envelhecimento acelerado e condutividade elétrica, a fim de avaliar a qualidade fisiológica de sementes de pitaia. Para o estudo foram utilizadas sementes de frutos maduros de Hylocereus undatus. O delineamento experimental foi o inteiramente casualizado, com quatro repetições. A qualidade fisiológica das sementes foi avaliada pelos testes de germinação, envelhecimento acelerado e condutividade elétrica, além da determinação do índice de velocidade de germinação (IVG) e do tempo médio de germinação (TMG), ambos, em conjunto

\footnotetext{
${ }^{1}$ Discentes do Curso de Doutorado do Programa de Pós-graduação em Agronomia, Dept ${ }^{\circ}$. de Agronomia, Universidade Estadual de Londrina, UEL, Londrina, PR, Brasil. Bolsistas CAPES. E-mail: thiago.ortiz@hotmail.com; alinemoritz6@hotmail.com

2 Prof $^{\mathrm{a}}$ Dra $^{\mathrm{a}}$, do Dept ${ }^{\mathrm{o}}$ de Agronomia, UEL, Londrina, PR, Brasil. E-mail: sadayo@uel.br

${ }^{3}$ Prof $^{\mathrm{a}} \mathrm{Dr}^{\mathrm{a}}$, do Dept $^{\mathrm{o}}$ de Estatística, UEL, Londrina, PR, Brasil. E-mail: mariana.ragasi@gmail.com

* Autor para correspondência
} 
aos testes de germinação e envelhecimento acelerado. Para a análise estatística foram feitos ajustes de modelos de regressão e cálculo do coeficiente de correlação de Pearson $(\mathrm{p}<0,05)$. O teste de germinação em sementes de $H$. undatus pode ser conduzido a $25^{\circ} \mathrm{C}$, tendo em vista alcançar maior IVG e menor TMG. O envelhecimento acelerado pode ser conduzido a $43{ }^{\circ} \mathrm{C}$ por $48 \mathrm{~h}$, já que a combinação destes fatores é favorável à expressão do vigor das sementes, alcançando o ponto de máximo e de mínimo do IVG e do TMG, respectivamente, além da economia de tempo na sua condução. $O$ teste de condutividade elétrica pode ser conduzido com 25 sementes, na temperatura de $30{ }^{\circ} \mathrm{C}$ e volume de água de $10 \mathrm{~mL}$, já que nesta condição, há menor interferência de fatores externos ao conteúdo de lixiviados na solução.

Palavras-chave: Envelhecimento acelerado, cactaceae, condutividade elétrica, germinação, Hylocereus undatus, vigor

\section{Introduction}

Pitaya [Hylocereus undatus (Haworth) Britton $\&$ Rose], a species from the Cactaceae family originated from tropical and subtropical America, occupies a growing niche in the exotic fruits market (LE BELLEC et al., 2006). It is raising the interest of consumers for its organoleptic characteristics and nutraceutical properties, since this and several other species of pitaya are rich in antioxidants, vitamins, and fibers, and are a source of vitamin A, phosphorus, calcium, potassium, and sodium (CRANE; BALERDI, 2005; WU et al., 2006; ESQUIVEL et al., 2007). It is also of interest to fruit growers due to an increase in its demand (BASTOS et al., 2006).

Pitaya can be sexually propagated in cultivation, which requires knowledge of possible factors influencing the assessments of the physiological quality of its seeds. Usually, the physiological potential of the seeds is determined using the germination pattern test; however, this test has been shown insufficient, as it has been performed under ideal conditions (RODO et al., 2000). Thus, vigor tests are becoming increasingly popular tools that are routinely used to complement the results obtained by the germination test (MIGUEL et al., 2001). Among others, these tests include those that are based on resistance to stress (accelerated aging and cold test) and the biochemical tests (electrical conductivity and tetrazolium tests) (VIEIRA; KRZYZANOWSKI, 1999).
The purpose of the accelerated aging test is to assess the physiological potential of the seeds. The interaction of temperature and exposure period is one of the most important factors affecting the behavior of the seeds subjected to this test and it varies among species. There are indications that a temperature of 40 to $45^{\circ} \mathrm{C}$ and an aging period between 48 and $96 \mathrm{~h}$ is the optimal combination of factors when testing the physiological potential of seeds in most of the cultures (MARCOS FILHO, 1999; FANAN et al., 2006).

The electrical conductivity test is based on an indirect assessment of the seeds' cellular membrane organization through determining the amount of leachate released by seeds into the imbibing solution. Several factors can affect the results of the electrical conductivity test, such as the imbibition period or temperature, the volume of water used, the presence of damages, and the quantity of seeds. One of the advantages of this test is the speed in obtaining the results, since a $24-\mathrm{h}$ imbibition period is the most recommended for the seeds of different species (VIEIRA; KRZYZANOWSKI, 1999).

The choice of the method used to assess seed vigor should prioritize speed, objectivity, simplicity, economy, and reproducibility, and in addition, allow the comparison of the data obtained from the tests used (CALIARI; SILVA, 2001). Thus, the use of different tests is necessary in order to compare the behavior of seed batches with accuracy in both laboratory and field. 
Since the literature does not highlight standardized procedures of vigor tests to assess the physiological quality of the seeds in several species, and the Standards for Seed Analysis (Regras para Análise de Sementes; RAS) do not recognize most of them, it is necessary to standardize methodologies that favor the applicability and reproducibility of the results. In addition, since there are few studies related to pitaya culture, it is worth to emphasize the need to conduct studies aiming to obtain practical information in order to optimize the physiological quality of the pitaya seeds and their productivity.

Therefore, given the importance of the germination test, the efficiency and practicality of vigor tests, and the possibility of applying these tests to different species, this work aimed to establish germination test as well as accelerated aging and electrical conductivity methodologies that can be used to evaluate the physiological quality of pitaya seeds.

\section{Materials and Methods}

This work was performed in the Seed Technology and Production Laboratory of the State University of Londrina (UEL), Londrina-PR. The seeds were obtained from ripe fruits of white-fleshed red pitaya (H. undatus) mother plants, aged approximately 10 years. The plants were cultivated in the experimental plot of the Department of Agronomy at UEL, located at $23^{\circ} 23^{\prime} \mathrm{S}$ and $51^{\circ} 11^{\prime} \mathrm{W}$, at an average elevation of $566 \mathrm{~m}$. Pitaya plants were grown in soil area classified as RED NITISOL Eutroferric latosol (EMBRAPA, 2013), planted every $2.0 \times 3.0 \mathrm{~m}$, and supported by 2.5 -m-high sticks, with two plants per stick.

The fruits were longitudinally sectioned, and the pulp and seeds were extracted with a spoon. The extracted pulp and seeds were incubated in a solution of water $(1 \mathrm{~L})$ and sucrose $\left(25 \mathrm{~g} \mathrm{~L}^{-1}\right)$ for $48 \mathrm{~h}$ at room temperature to facilitate fermentation and seed extraction. After the incubation period, the solution was sieved under running water to eliminate pulp residues and preserve the seeds, which were then placed on filter paper and shade dried at room temperature for $48 \mathrm{~h}$ (ORTIZ et al., 2015).

The experimental design was completely randomized with four replicates. The physiological quality of the seeds was evaluated using the following tests:

Germination: 50 seeds were used in each replicate and were placed in crystal polyethylene boxes $\left(G^{-}\right.$rbox $^{\circledR}$ type), lined with filter paper that was moistened with distilled water to 2.5 times the dry mass of the substrate. The germination test was conducted in germination chambers in the dark, at temperatures of 20,25 , or $30^{\circ} \mathrm{C}$, corresponding to the treatments of each sample.

Accelerated aging: four subsamples of 50 seeds were used for each treatment and distributed in a single layer over a nylon mesh fixed inside the crystal polyethylene box (Gerbox ${ }^{\circledR}$ type); $40 \mathrm{~mL}$ of distilled water was added at the bottom of the box. Replicates were conditioned in germination chambers at temperatures of 41,43 , and $45{ }^{\circ} \mathrm{C}$ during 48,72, and $96 \mathrm{~h}$, in a $3 \times 3$ factorial design (temperature $\times$ exposure period). After each exposure period, the treatments were submitted to the germination test conducted in a germination chamber at $25{ }^{\circ} \mathrm{C}$ in the dark. This temperature was used because it was confirmed ideal for the species under study in previous germination tests.

The evaluation of germination and accelerated aging tests was conducted daily until the germination process stabilized. Seeds were considered germinated when the radicle elongated $5 \mathrm{~mm}$ or more; the results were expressed as percentage of germinated seeds. In addition, for each test was determined the speed of germination index (SGI) according to the methodology proposed by Maguire (1962) and the mean germination time (MGT), expressed in days, according to protocol described by Lima et al. (2006). 
Electrical conductivity: the test was conducted using 25 and 50 seeds. For each quantity of seeds, five volumes of water $(10,20,30,40$, and $50 \mathrm{~mL})$ and three different temperatures of imbibition (20, 25 , and $30^{\circ} \mathrm{C}$ ) were evaluated in a $5 \times 3$ factorial design. For each experimental unit, adequate number of seeds was placed in containers and treated with $10,20,30,40$, or $50 \mathrm{~mL}$ of deionized water. Then, the containers were incubated at 20 , 25 , or $30{ }^{\circ} \mathrm{C}$ in germination chambers. The readings were performed after $24 \mathrm{~h}$ using a conductivity meter (HI 98331 ${ }^{\circledR}$ Hanna Instruments, São Paulo, Brazil) and the average values were calculated and expressed in $\mu \mathrm{S} \mathrm{cm}^{-1}$.

The statistical analyses were performed using the software program $\mathrm{R}$ ( $\mathrm{R}$ DEVELOPMENT CORE TEAM, 2015). Adjustments were conducted on the regression model, with quadratic terms for SGI and MGT variables of the germination test; response surface for SGI and MGT variables of the accelerated aging and for electrical conductivity test, and the Pearson's correlation coefficient ( $\mathrm{p}$ $<0.05)$ for the variables of the germination and accelerated aging tests were calculated.

\section{Results and Discussion}

The germination rate of pitaya (H. undatus) seeds did not differ significantly among the temperatures that were evaluated $\left(20,25\right.$, and $30{ }^{\circ} \mathrm{C}$ ) (data not shown). Alves et al. (2011), evaluated the paper, sand, vermiculite, and soil substrates under constant and alternating temperatures of 20,25 , and $30^{\circ} \mathrm{C}$ and 20-30 ${ }^{\circ} \mathrm{C}$, and observed that the paper substrate and a temperature of $25{ }^{\circ} \mathrm{C}$ were favorable conditions for the initial and final evaluation of germination rate of pitaya seeds.

Andrade et al. (2008) evaluated six substrates for the germination of the pitaya seed. They also observed a significant difference among the substrates and found that filter paper is the more adequate substrate, because it does not impede or create physical barrier to the protrusion of radicle from these small seeds. Therefore, the present study was conducted using only filter paper as a substrate.

It is worth mentioning that the germination rate of seeds grown on filter paper in the study by Andrade et al. (2008) is considerably lower than that observed in this study $(60 \%$ vs. 95 to $98 \%$, respectively), whereas the maximum germination rate of seeds grown on a paper roll at $25^{\circ} \mathrm{C}$ obtained by Alves et al. (2011) was $85 \%$.

In addition, Andrade et al. (2008) took 12 weeks to stabilize the germination process. This time was higher than the time required in this study since the stabilization of the germination process was achieved in 9,8 , and 25 days at 20,25 , and $30^{\circ} \mathrm{C}$, respectively, after the start of the tests. Alves et al. (2011) observed that in all substrates, germination ceased 10 days after sowing, which was similar to the results obtained in this study. The ideal temperature for the germination of a species tends to require less time for stabilization of the seed germination process, and thereby the germination is faster; this conclusion was corroborated by the SGI and MGT variables (Figure 1).

Regression model adjustments were performed using quadratic terms for SGI and MGT as a function of the temperature (Figure 1). Figure 1A shows that the increase of the temperature from $20{ }^{\circ} \mathrm{C}$ to $25^{\circ} \mathrm{C}$ favored the SGI, which peaked at this temperature and subsequently decreased at $30{ }^{\circ} \mathrm{C}$. The temperature of $25^{\circ} \mathrm{C}$ was again confirmed beneficial when analyzing the MGT (Figure 1B) since the minimum value was obtained at $25{ }^{\circ} \mathrm{C}$ (4.69 days). This is satisfactory, since under field conditions, the seeds would be less exposed to bad weather. These results confirmed that the germination test of $H$. undatus seeds produces more favorable results when conducted at $25^{\circ} \mathrm{C}$. 
Figure 1. A - Speed of germination index (SGI) and B - Mean germination time (MGT), in days, of Hylocereus undatus seeds at different temperatures $\left(20,25\right.$, and $\left.30^{\circ} \mathrm{C}\right)$.

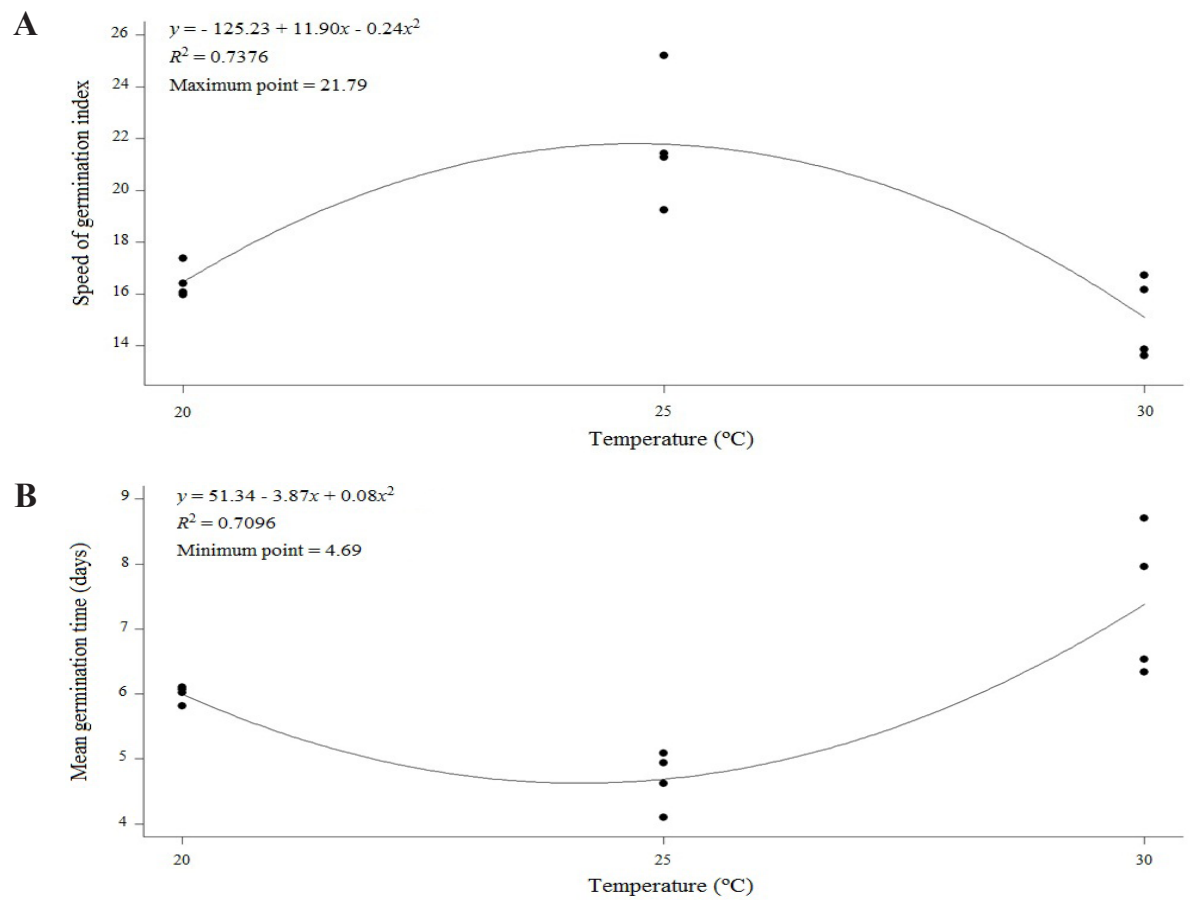

In the correlation analysis, a correlation coefficient $(\rho)$ above 0.80 indicates strong significant correlation and less than 0.80 is considered medium correlation (ORTIZ et al., 2014). The analysis of the correlation between the germination rate, SGI, and MGT, obtained through the germination test, indicated a strong linear and inversely proportional correlation $(\rho=-0.90)$ between the SGI and MGT; that is, as the germination speed increases the time required for the germination to occur decreases. The variable germination rate exhibited a medium correlation, being directly proportional to SGI ( $\rho$ $=0.62$ ) and inversely proportional to MGT ( $\rho=$ $-0.55)$. The test for the correlation significance was performed using the correlation coefficients, and a value of $\mathrm{p}<0.05$ was obtained for all coefficients.

The germination variable, obtained from the accelerated aging test in $H$. undatus seeds, did not differ significantly when evaluating different exposure periods (48, 72, and $96 \mathrm{~h}$ ) and temperatures (41, 43, and $45^{\circ} \mathrm{C}$ ) (data not shown). Similarly, Coimbra et al. (2009) did not observe any statistical differences for the same exposure periods in Zea mays L. seeds.

Nevertheless, Oro et al. (2012), who worked with Physalis peruviana L. seeds, observed a significant difference when evaluating the exposure period (24, 48 , and $72 \mathrm{~h}$ ), germination rate decreased as the duration of the aging treatment increased. Ataíde et al. (2012), when testing three exposure periods (24, 48, and 72 h), in Pterogyne nitens Tull. seeds, observed that seed vigor was reduced after $24 \mathrm{~h}$, an effect attributable to the high temperature associated with the increased water content in these seeds, which caused an increase in their metabolism.

Tunes et al. (2012a) assessed five exposure periods (24, 48, 72, 96, and $120 \mathrm{~h}$ ) in Oryza sativa L. seeds and observed a decrease in germination with increased exposure period. The effect was greatly exacerbated after 96 and $120 \mathrm{~h}$ of exposure, which were shown to be inadequate for seeds belonging to this species. Similar results were obtained by Pedroso et al. (2010) and Tunes et al. (2012b) in Triticum aestivum L. and Brassica oleracea L. var. 
italica Plenk seeds, respectively, in which they found that the stress caused by the 96-h accelerated aging test significantly reduced the germination rate of these seeds.

According to Santos et al. (2002), the increase in temperature promotes more drastic effects on the germination of $Z$. mays seeds than extending the period of exposure to accelerated aging, as both the temperatures of $42{ }^{\circ} \mathrm{C}$ and $45{ }^{\circ} \mathrm{C}$ linearly decrease germination over the exposure time. It is worth emphasizing that each species presents a different behavior to the tested conditions. Thus, it is necessary to evaluate the factors of interest for each species under study. Many studies detected significant effects of temperature and exposure period in different species; however, this was not observed in pitaya seeds.

The analysis of the SGI from the accelerated aging test indicate that there was no interaction between the factors (Figure 2); nevertheless, the temperature exhibited a quadratic pattern of behavior, and the exposure period varied linearly. The indexes were lower at $45^{\circ} \mathrm{C}$, with the SGI peak occurring at $43{ }^{\circ} \mathrm{C}$. In relation to the exposure period, the behavior was the same for all the temperatures assessed; that is, $96 \mathrm{~h}$ contributed to the decrease in seed vigor, as indicated by the lowest SGI values, and $48 \mathrm{~h}$ was determined to be the optimal time to conduct the test, since germination speed was the highest during this period.

Figure 2. Surface response for speed of germination index (SGI) obtained during the accelerated aging test with Hylocereus undatus seeds as a function of the temperature (x) and exposure period (y).

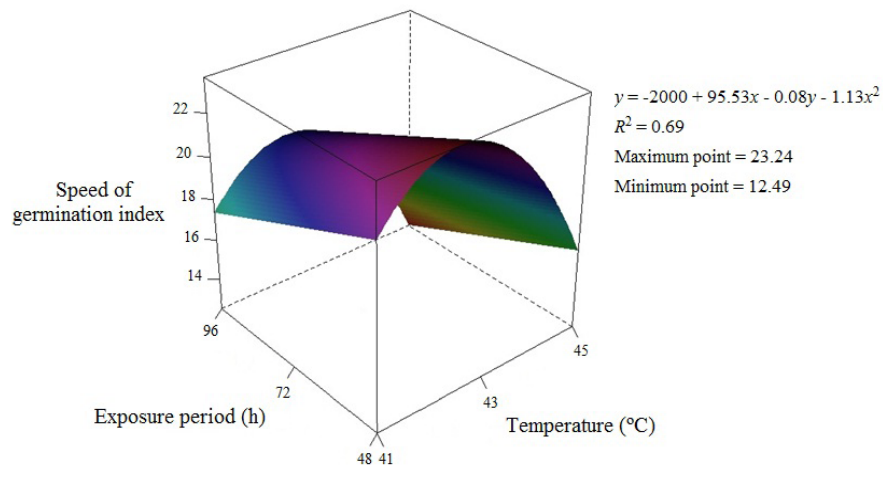

Regarding the MGT, the temperature of $43{ }^{\circ} \mathrm{C}$ also resulted in the highest vigor, taking less time for the germination process (Figure 3 ). In addition, the decrease in exposure period from 96 to $48 \mathrm{~h}$ favored the reduction of the MGT, which is an advantage, since the shorter time required to conduct the test and less influence of external factors on the vigor. So, the vigor is predominantly dependent on the seed quality and not on the adverse conditions to which these were subjected.

Pereira et al. (2012) evaluated three temperatures (41, 42, and $\left.45^{\circ} \mathrm{C}\right)$ and four aging periods (24,
48, 72, and $96 \mathrm{~h}$ ). They observed that $45^{\circ} \mathrm{C}$ was the most limiting temperature for the Jatropha curcas L. seeds. This temperature was also the most restrictive for $H$. undatus seeds as inferred from to the SGI and MGT variables (Figures 2 and 3). Similarly, Mendes et al. (2010) observed that temperature of $45^{\circ} \mathrm{C}$ and the periods of 48,72 , and $96 \mathrm{~h}$ were damaging to the Ricinus communis $\mathrm{L}$. seeds, accelerating their deterioration. According to Marcos Filho (1999), the increase in temperature is one of the factors contributing to accelerated seed deterioration, according to the basic principles of the accelerated aging test. 
Figure 3. Surface response for mean germination time (MGT), in days, obtained from the accelerated aging test with Hylocereus undatus seeds as a function of the temperature (x) and exposure period (y).

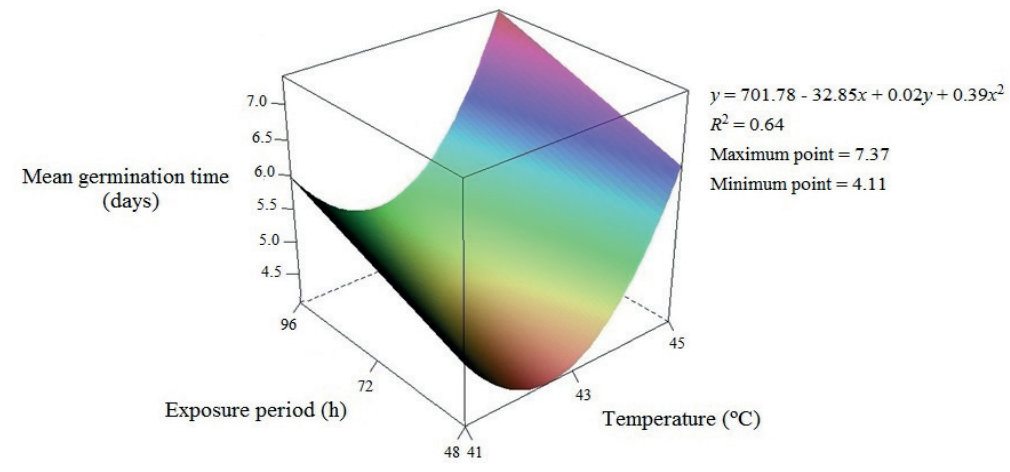

Pedroso et al. (2010), in their analysis of $T$. aestivum seed performance in the accelerated aging test at $42{ }^{\circ} \mathrm{C}$ over 48,72 , and $96 \mathrm{~h}$, observed a reduction in germination rate after aging, indicating that the procedure using the exposure of $96 \mathrm{~h}$ is not the most adequate for this species. This adverse effect is also confirmed in the present study of $H$. undatus seeds, which is indicated by the decrease in SGI and increase in MGT in seeds exposed for $96 \mathrm{~h}$ in an aging chamber.

Thus, the maximum and minimum points for SGI and the minimum and maximum points for MGT were reached at $43{ }^{\circ} \mathrm{C} / 48 \mathrm{~h}$ and $45{ }^{\circ} \mathrm{C} / 96 \mathrm{~h}$, respectively. According to the results obtained, the accelerated aging test conducted at a temperature of $43{ }^{\circ} \mathrm{C}$ and over an exposure period of $48 \mathrm{~h}$ showed to be promising in the evaluation of the pitaya seeds vigor, as these conditions provide the best performance (vigor). In other words, the physiological quality of the seeds was less affected by external factors, which was observed for both variables (SGI and MGT). This reflects the vigor of the sample and decreases the time required to perform this test, due to a decreased length of the aging exposure treatment.

The Pearson correlation was also used to analyze the variables obtained from the accelerated aging test. The interaction between SGI and MGT was once again highlighted, showing a strong and inversely proportional correlation ( $\rho=-0.96)$. In addition, there was a correlation between the germination rate and SGI $(\rho=0.72)$, and between germination rate and MGT $(\rho=-0.59)$. The test for the correlation coefficients was conducted between all variables and the significant values were determined at $\mathrm{p}<0.05$.

Preliminary tests were performed to carry out the electrical conductivity test, in order to assess the behavior of the seeds in relation to the factors under study (quantity of seeds, temperature, and volume of the water). These results (data not shown) showed that the immersion period of pitaya seeds should not be less than $24 \mathrm{~h}$, given that data could not be collected from the samples under most of the conditions tested if the seeds were immersed for less than $24 \mathrm{~h}$. However, this time should also not be extended beyond $24 \mathrm{~h}$, since after this point radicle protrudes from pitaya seeds as these undergo rapid germination. Thus, the electrical conductivity test for H. undatus seeds should be conducted for $24 \mathrm{~h}$, which is the most commonly recommended immersion period for different species (VIEIRA; KRZYZANOWSKI, 1999).

According to Dias et al. (2006), the most efficient period to classify Allium cepa L. seed batches in relation to performance levels using the electrical conductivity test is $24 \mathrm{~h}$, since these present changes in the ordination of the batches according to the degree of humidity of the seeds and the volume of water used to perform the test. Fessel et al. (2005) also recommend the use of a 24-h immersion period to assess the electrical 
conductivity of $B$. oleracea seeds.

The results of the electrical conductivity test conducted using 25 seeds showed no significant interaction between water volume and temperature; however, when considered separately, both were significant and exhibited quadratic behavior (Figure 4). Similarly, Albuquerque et al. (2001) determined the separate effect of the imbibition temperature in Helianthus annuus L. seeds.

Figure 4. Surface response for electrical conductivity $\left(\mu \mathrm{S} \mathrm{cm}^{-1}\right)$ using 25 Hylocereus undatus seeds as a function of the temperature $(\mathrm{x})$ and exposure period $(\mathrm{y})$.

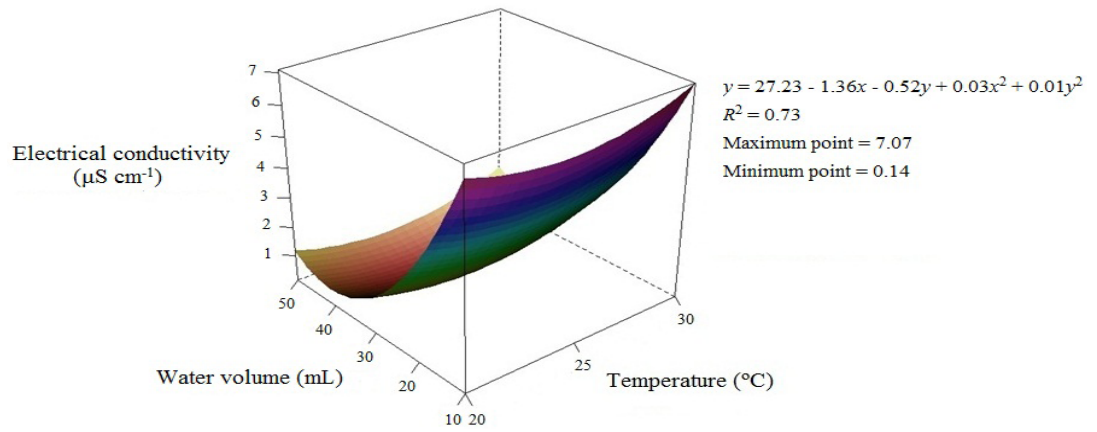

However, Milani et al. (2012) observed a significant triple interaction $(p<0.05)$ when assessing the methodology of the electrical conductivity test (four batches; two volumes of water, 25 and $50 \mathrm{~mL}$; and five immersion periods, 2, 4, 8, 16, and 24 h) using Brassica napus L. var. oleifera seeds, indicating that the seed batches behaved differently in each combination of water volume and immersion period. In addition, Ribeiro et al. (2009) observed the influence of the temperature, immersion period, and volume of water on the electrical conductivity of different $Z$. mays batches.

The analysis of the temperature revealed that lower values of electrical conductivity were obtained at $25{ }^{\circ} \mathrm{C}$. The conductivity decreased, not only with the increase of temperature from $20{ }^{\circ} \mathrm{C}$ to $25{ }^{\circ} \mathrm{C}$, but also with the decrease of temperature from $30{ }^{\circ} \mathrm{C}$ to $25^{\circ} \mathrm{C}$, and during the latter change, the decrease was more pronounced (Figure 4). This may be attributable to the fact that a temperature of $30{ }^{\circ} \mathrm{C}$ produces higher values of electrical conductivity, and a temperature of $20^{\circ} \mathrm{C}$ provides intermediate values. The results obtained by Albuquerque et al. (2001) for H. annuus seeds and Fessel et al. (2005) for B. oleracea seeds are supported with the results obtained in this study, in which it was found that the temperatures of $30{ }^{\circ} \mathrm{C}$ and $20{ }^{\circ} \mathrm{C}$, respectively, contributed to a significantly higher release of electrolytes than a temperature of $25^{\circ} \mathrm{C}$. According to Ribeiro et al. (2009), the use of a higher temperature, combined with an increase in the imbibition period, was shown to be an efficient method for the assessment of the vigor in $Z$. mays seeds.

It was observed that in relation to the volume of water, a volume of 50,40, and $30 \mathrm{~mL}$ produced a similar behavior, with values of electrical conductivity that were almost equal to zero. This means that these volumes were too large to allow for the detection of leachates in the immersion solution, since leachates were detected in lower volumes (20 and $10 \mathrm{~mL}$ ). When using $20 \mathrm{~mL}$ of water and 25 pitaya seeds, we observed a pronounced increase in the electrical conductivity, and the increase was even more pronounced when using $10 \mathrm{~mL}$ of water. Therefore, this volume proved to be beneficial, as it minimizes the influence of the external factor 
(volume of water), and allows for the detection of leachates from the batch of seeds tested.

Pereira and Martins Filho (2012) observed that, when using a higher volume of water with Solanum sessiliflorum Dunal seeds, it was not possible to observe the stratification of the batches in relation to the vigor using the electrical conductivity test as accurately as when using a lower volume of water. This suggests that the increase in water volume dilutes the imbibing solution and that the decrease in the conductivity values may decrease the efficiency of assessing seed vigor by using this test.

Other authors also observed that the decrease in water volume is associated with higher electrical conductivity values; for example, this was reported by Fessel et al. (2005) in B. oleracea, Ribeiro et al. (2009) in Z. mays, Soares et al. (2010) in Sorghum bicolor [L.] Moench, Machado et al. (2011) in Pisum sativum L. subsp. arvense, Ataíde et al. (2012) in $P$. nitens, and Milani et al. (2012) in B. napus.

Similar to the electrical conductivity test performed with 25 seeds, the test using 50 pitaya seeds revealed no significant interaction between the water volume and temperature; however, individually both factors were significant, exhibiting a quadratic behavior (Figure 5).

Regarding the temperatures, the lowest electrical conductivity values were obtained at $20{ }^{\circ} \mathrm{C}$ and $25{ }^{\circ} \mathrm{C}$, suggesting that with the increase in temperature the electrical conductivity increase, peaking at $30{ }^{\circ} \mathrm{C}$ (Figure 5). This behavior was also observed in the tests using 25 seeds, in which the analysis of the temperature range revealed that the electrical conductivity values increased at $30{ }^{\circ} \mathrm{C}$ (Figure 4).

Dutra et al. (2007) observed that the increase in temperature from $20^{\circ} \mathrm{C}$ to $25^{\circ} \mathrm{C}$ or $30^{\circ} \mathrm{C}$, in Senna siamea [Lam.] H.S. Irwin \& Barneby seeds increased the leaching of exudates, with the greatest leaching of ions observed at $30{ }^{\circ} \mathrm{C}$ and the lowest at $20^{\circ} \mathrm{C}$. Thus, $30^{\circ} \mathrm{C}$ is the recommended temperature for conducting the electrical conductivity test on seeds of this species. Similar results were obtained when electrical conductivity was tested using 50 pitaya seeds (Figure 5). This result was probably due to the increase in the imbibition temperature, which is related to alterations in the viscosity of the solution and an increase in the activation energy (mobility) of the ions, and consequently to an increase in the quantity and speed of electrolyte leaching (MACHADO et al., 2011).

Figure 5. Surface response for electrical conductivity $\left(\mu \mathrm{S} \mathrm{cm}^{-1}\right)$ using 50 Hylocereus undatus seeds as a function of the temperature (x) and exposure period (y).

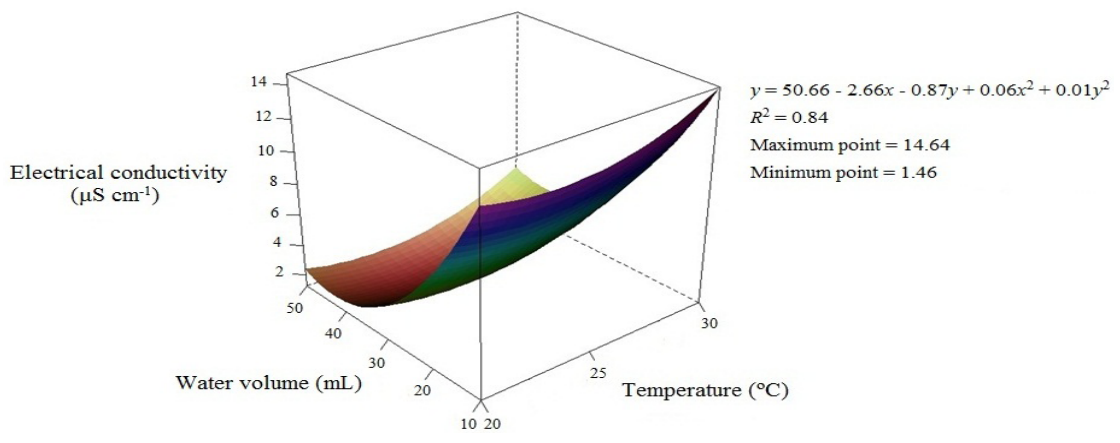

Regarding the volume of water, it was observed that in the experiment with 50 seeds, water volumes of 50 and $40 \mathrm{~mL}$ promoted the expression of lower electrical conductivity values as a consequence of lower concentration of the solution. This indicates that these water volumes were excessive for the 
electrical conductivity test. In $30 \mathrm{~mL}$ of water, there was an increase in the conductivity; however, when the water volume was decreased from 30 to $10 \mathrm{~mL}$, an even greater increase was observed when the reading was performed using a conductivity probe. Therefore, higher concentration of leachates detected when lower volumes are used suggest that the lower values are favorable for conducting this test, in both experiments with 25 and 50 seeds. The highest values were obtained with $10 \mathrm{~mL}$ of water for all three temperatures assessed.

The results of this study are corroborated with those presented in previous studies; for example, the work conducted by Vidigal et al. (2008), who evaluated the electrical conductivity test using 25 and 50 Capsicum spp. seeds and two water volumes (25 and $50 \mathrm{~mL}$ ), found that the release was considerably higher, regardless of the amount of seeds, when the seeds were soaked in a smaller volume of water. According to Milani et al. (2012), the lower dilution of leachates (50 seeds in $25 \mathrm{~mL}$ ) differentiates the quality of the batches in a shorter immersion time than the higher dilution (50 seeds in $50 \mathrm{~mL}$ ).

Thus, the minimum and maximum points were obtained when conducting the electrical conductivity test with both 25 and 50 seeds at $25^{\circ} \mathrm{C} / 40 \mathrm{~mL}$ of water and at $30^{\circ} \mathrm{C} / 10 \mathrm{~mL}$ of water, respectively. It is worth emphasizing that the values of electrical conductivity obtained in experiments with 25 seeds (maximum point of $7.07 \mu \mathrm{S} \mathrm{cm}^{-1}$ ) were lower than those obtained with 50 seeds (maximum point of $14.64 \mu \mathrm{S} \mathrm{cm}^{-1}$ ). According to Menezes et al. (2007), the use of 25 seeds allowed for a more efficient separation of batches of Avena strigosa Schreb with different levels of vigor due to its higher sensitivity compared to the sensitivity obtained with 50 seeds.

Fessel et al. (2005), in their evaluation of nine batches of $B$. oleracea, observed that the different number of seeds used $(25,50$, and 75$)$ did not affect significantly the values of electrical conductivity of eight batches. Therefore, the authors recommended using the lowest number of seeds in order to reduce costs, because one of the main trouble for vegetables production is the high cost of seeds. Their results agree with the studies by Araujo et al. (2011), in which one of the objectives of the laboratory tests is to minimize the quantity of seeds needed in addition to reducing the period necessary to carry out the test. However, adjustments to the electrical conductivity test methodology are important to ensure consistent results (DIAS et al., 2006).

Nevertheless, it is known that several factors are able to interfere the seed vigor expression. This underlines the importance of studies to standardize the methodology for all species. Therefore, it is necessary to assess the effect of factors for each vigor test in the seed quality of each species, as to employ various tests (preferably with different principles) that will provide complementary information, in order to determine the final destination of the seed batch.

Furthermore, new studies on pitaya seeds are needed to compare the behavior of different seed batches with different vigor levels within this species, in order to check if all batches exhibit sensitivity to the conditions to which the seeds from the present study were subjected or if seed vigor is reflected in their behavior.

\section{Conclusion}

The germination test for $H$. undatus seeds can be conducted at $25^{\circ} \mathrm{C}$, which will maximize the SGI and minimize the MGT.

The accelerated aging test can be conducted at $43{ }^{\circ} \mathrm{C}$ for $48 \mathrm{~h}$, since the combination of these factors is favorable for the expression of seed vigor, reaching the maximum and minimum points of the SGI and MGT, respectively. In addition, this shortens the duration of the test.

The electrical conductivity test can be performed using 25 seeds at a temperature of $30^{\circ} \mathrm{C}$ and a water volume of $10 \mathrm{~mL}$, since under these conditions there 
is a lower interference from external factors on the detection of leachates in the solution.

\section{Acknowledgements}

We would like to thank the Coordenação de Aperfeiçoamento de Pessoal de Nível Superior (CAPES) for the scholarships awarded to the authors.

\section{References}

ALBUQUERQUE, M. C. F. E.; MORO, F. V.; FAGIOLI, M.; RIBEIRO, M. C. Testes de condutividade elétrica e de lixiviação de potássio na avaliação da qualidade fisiológica de sementes de girassol. Revista Brasileira de Sementes, Brasília, v. 23, n. 1, p. 1-8, 2001.

ALVES, C. Z.; GODOY, A. R.; CORRÊA, L. S. Adequação da metodologia para o teste de germinação de sementes de pitaia vermelha. Ciência Rural, Santa Maria, v. 41, n. 5, p. 779-784, 2011.

ANDRADE, R. A.; OLIVEIRA, I. V. M.; SILVA, M. T. H.; MARTINS, A. B. G. Germinação de pitaya em diferentes substratos. Revista Caatinga, Mossoró, v. 21, n. 1, p. 71-75, 2008.

ARAUJO, R. F.; ZONTA, J. B.; ARAUJO, E. F.; HEBERLE, E.; ZONTA, F. M. G. Teste de condutividade elétrica para sementes de feijão-mungo-verde. Revista Brasileira de Sementes, Londrina, v. 33, n. 1, p. 123-130, 2011.

ATAIIDE, G. M.; FLORES, A. V.; BORGES, E. E. L.; RESENDE, R. T. Adequação da metodologia do teste de condutividade elétrica para sementes de Pterogyne nitens Tull. Revista Brasileira de Ciências Agrárias, Recife, v. 7, n. 4, p. 635-640, 2012.

BASTOS, D. C.; PIO, R.; SCARPARE FILHO, J. A.; LIBARDI, M. N.; ALMEIDA, L. F. P.; GALUCHI, T. P. D.; BAKKER, S. T. Propagação da Pitaya 'vermelha' por estaquia. Ciência e Agrotecnologia, Lavras, v. 30, n. 6, p. 1106-1109, 2006.

CALIARI, M. F.; SILVA, W. R. Interpretação de dados de testes de vigor na avaliação da qualidade fisiológica de sementes de milho. Revista Brasileira de Sementes, Brasília, v. 23, n. 1, p. 239-251, 2001.

COIMBRA, R. A.; MARTINS, C. C.; TOMAZ, C. A.; NAKAGAWA, J. Testes de vigor utilizados na avaliação da qualidade fisiológica de lotes de sementes de milhodoce (sh2). Ciência Rural, Santa Maria, v. 39, n. 9, p. 2402-2408, 2009.
CRANE, J. H.; BALERDI, C. F. Pitaya growing in the Florida home landscape. Institute of Food and Agricultural Sciences (IFAS Extension). Orlando: University of Florida, 2005. HS 1068. 9 p. Available at: <https://edis.ifas.ufl.edu/pdffiles/HS/HS30300.pdf > . Accessed at: 20 out. 2015.

DIAS, D. C. F. S.; BHERING, M. C.; TOKUHISA, D.; HILST, P. C. Teste de condutividade elétrica para avaliação do vigor de sementes de cebola. Revista Brasileira de Sementes, Pelotas, v. 28, n. 1, p. 154-162, 2006.

DUTRA, A. S.; MEDEIROS FILHO, S.; DINIZ, F. O. Teste de condutividade elétrica em sementes de Senna siamea (Lam.) H.S. Irwin \& Barneby. Revista Ciência Agronômica, Fortaleza, v. 38, n. 3, p. 280-285, 2007.

EMPRESA BRASILEIRA DE PESQUISA AGROPECUÁRIA - EMBRAPA. Sistema brasileiro de classificação de solos. 3. ed. Brasília: Embrapa, 2013. $353 \mathrm{p}$.

ESQUIVEL， P.; STINTZING，F. C.; CARLE，R. Comparison of morphological and chemical fruit traits from different pitaya genotypes (Hylocereus $\mathrm{sp}$.) grown in Costa Rica. Journal of Applied Botany and Food Quality, v. 81, n. 1, p. 7-14, 2007.

FANAN, S.; MEDINA, P. F.; LIMA, T. C.; MARCOS FILHO, J. Avaliação do vigor de sementes de trigo pelos testes de envelhecimento acelerado e de frio. Revista Brasileira de Sementes, Pelotas, v. 28, n. 2, p. 152-158, 2006.

FESSEL, S. A.; SILVA, L. J. R.; SADER, R. Teste de condutividade elétrica para avaliar a qualidade fisiológica de sementes de brócolis (Brassica oleracea L. var. italica Plenk). Científica, Jaboticabal, v. 33, n. 1, p. 35-41, 2005.

LE BELLEC, F.; VAILLANT, F.; IMBERT, E. Pitahaya (Hylocereus spp.): a new crop, a market with a future. Fruits, Paris, v. 61, n. 4, p. 237-250, 2006.

LIMA, J. D.; ALMEIDA, C. C.; DANTAS, V. A. V.; SILVA, B. M. S.; MORAES, W. S. Efeito da temperatura e do substrato na germinação de sementes de Caesalpinia ferrea Mart. ex Tul. (Leguminosae, Caesalpinoideae). Revista Árvore, Viçosa, v. 30, n. 4, p. 513-518, 2006.

MACHADO, C. G.; MARTINS, C. C.; SANTANA, D. G.; CRUZ, S. C. S.; OLIVEIRA, S. S. C. Adequação do teste de condutividade elétrica para sementes de Pisum sativum subsp. Arvense. Ciência Rural, Santa Maria, v. 41, n. 6, p. 988-995, 2011. 
MAGUIRE, J. D. Speed of germination-aid in selection and evaluation for seedling emergence and vigor. Crop Science, Madison, v. 2, n. 2, p. 176-177, 1962.

MARCOS FILHO, J. Teste de envelhecimento acelerado. In: KRZYZANOWSKI, F. C.; VIEIRA, R. D.; FRANÇA NETO, J. B. (Ed.). Vigor de sementes: conceitos e testes. Londrina: Abrates, 1999. cap. 3, p. 1-24.

MENDES, R. C.; DIAS, D. C. F. S.; PEREIRA, M. D.; DIAS, L. A. S. Testes de vigor para avaliação do potencial fisiológico de sementes de mamona (Ricinus communis L.). Ciência e Agrotecnologia, Lavras, v. 34, n. 1, p. 114-120, 2010.

MENEZES, N. L.; GARCIA, D. C.; BAHRY, C. A.; MATTIONI. N. M. Teste de condutividade elétrica em sementes de aveia preta. Revista Brasileira de Sementes, Londrina, v. 29, n. 2, p. 138-142, 2007.

MIGUEL, M. H.; CARVALHO, M. V.; BECKERT, O. P.; MARCOS FILHO, J. Teste de frio para avaliação do potencial fisiológico de sementes de algodão. Scientia Agricola, Piracicaba, v. 58, n. 4, p. 741-746, 2001.

MILANI, M.; MENEZES, N. L.; LOPES, S. J. Teste de condutividade elétrica para avaliação do potencial fisiológico de sementes de canola. Revista Ceres, Viçosa, v. 59 , n. 3, p. 374-379, 2012.

ORO, P.; VILLA, F.; DARTORA, J.; MARINI, D.; MATTIELlO, V. D.; FAVORITO, P. A. Metodologia para teste de envelhecimento acelerado em sementes de fisális (Physalis peruviana). Cultivando o Saber, Cascavel, v. 5, n. 3, p. 167-175, 2012.

ORTIZ, T. A.; LONE, A. B.; UNEMOTO, L. K.; ATHANÁZIO, J. C.; TAKAHASHI, L. S. A. Metodologias para avaliação da qualidade fisiológica de lotes de sementes de cenoura cultivar Londrina armazenados por até dez anos. Bioscience Journal, Uberlandia, v. 30, p. 330-337, 2014. Suplemento 1.

ORTIZ, T. A.; MORITZ, A.; OLIVEIRA, M. A.; TAKAHASHI, L. S. A. Effects of the hydrogen potential and fungicide treatment on Pitaya seed germination. Acta Scientiarum. Agronomy, Maringá, v. 37, n. 1, p. 69-74, 2015.

PEDROSO, D. C.; TUNES, L. M.; BARBIERI, A. P.; BARROS, A. C. S. A.; MUNIZ, M. F. B.; MENEZES, V. O. Envelhecimento acelerado em sementes de trigo. Ciência Rural, Santa Maria, v. 40, n. 11, p. 2389-2392, 2010.

PEREIRA, M. D.; MARTINS FILHO, S. Adequação da metodologia do teste de condutividade elétrica para sementes de cubiu (Solanum sessiliflorum DUNAL). Revista Agrarian, Dourados, v. 5, n. 16, p. 93-98, 2012.
PEREIRA, M. D.; MARTINS FILHO, S.; LAVIOLA, B. G. Envelhecimento acelerado de sementes de pinhãomanso. Pesquisa Agropecuária Tropical, Goiânia, v. 42, n. 1, p. 119-123, 2012.

R DEVELOPMENT CORE TEAM. R Foundation for statistical computing. Vienna: Austria, 2015.

RIBEIRO, D. M.; BRAGANÇA, S. M.; GONELI, A. L. D.; DIAS, D. C. F. S.; ALVARENGA, E. M. Teste de condutividade elétrica para avaliar o vigor de sementes em milho-pipoca (Zea mays L.). Revista Ceres, Viçosa, v. 56, n. 6, p. 772-776, 2009.

RODO, A. B.; PANOBIANCO, M.; MARCOS FILHO, J. Metodologia alternativa do teste de envelhecimento acelerado para sementes de cenoura. Scientia Agricola, Piracicaba, v. 57, n. 2, p. 289-292, 2000.

SANTOS, P. M.; GONDIM, T. C. O.; ARAÚJO, E. F.; DIAS, D. S. F. S. Avaliação da qualidade fisiológica de sementes de milho-doce pelo teste de envelhecimento acelerado. Revista Brasileira de Sementes, Londrina, v. 24, n. 1, p. 91-96, 2002.

SOARES, M. M.; CONCEIÇÃO, P. M.; DIAS, D. C. F. S.; ALVARENGA, E. M. Testes para avaliação do vigor de sementes de sorgo com ênfase à condutividade elétrica. Ciência e Agrotecnologia, Lavras, v. 34, n. 2, p. 391-397, 2010.

TUNES, L. M.; TAVARES, L. C.; BARROS, A. C. S. A. Envelhecimento acelerado como teste de vigor para sementes de arroz. Revista de Ciências Agrárias, Lisboa, v. 35, n. 1, p. 120-127, 2012a.

TUNES, L. M.; TAVARES, L. C.; RUFINO, C. A.; BARROS, A. C. S. A.; MUNIZ, M. F. B.; DUARTE, V. B. Envelhecimento acelerado em sementes de brócolis (Brassica oleracea L. var. italica Plenk). Bioscience Journal, Uberlândia, v. 28, n. 2, p. 173-179, 2012 b.

VIDIGAL, D. S.; LIMA, J. S.; BHERING, M. C.; DIAS, D. C. F. S. Teste de condutividade elétrica para semente de pimenta. Revista Brasileira de Sementes, Londrina, v. 30, n. 1, p. 168-174, 2008.

VIEIRA, R. D.; KRZYZANOWSKI, F. C. Teste de condutividade elétrica. In: KRZYZANOWSKI, F. C.; VIEIRA, R. D.; FANÇA NETO, J. B. (Ed.). Vigor de sementes: conceitos e testes. Londrina: Abrates, 1999. cap. 4, p. 1-26.

WU, L. C.; HSU, H. W.; CHEN, Y. C.; CHIU, C. C.; LIN, Y. I.; HO, J. A. Antioxidant and antiproliferative activities of red pitaya. Food Chemistry, London, v. 95, n. 2, p. 319-327, 2006. 